Chapter 2

\title{
Development of an Environmentally Advanced Basin Model in Asia
}

\author{
Kazuo Oki, Keigo Noda, Koshi Yoshida, \\ Issaku Azechi, Masayasu Maki, Koki Homma, \\ Chiharu Hongo and Hiroaki Shirakawa \\ Additional information is available at the end of the chapter \\ http://dx.doi.org/10.5772/54926
}

\section{Introduction}

Tropical regions support a large number of plant and animal species, and conservation of these regions is a major issue that must be tackled globally, not only by the nations in tropical regions. Agriculture has a major impact on the environment in tropical regions, including Asian nations, which face four issues in relation to the environment.

The first issue is the expansion of cultivated land and the accompanying increase in water demand. At issue is land use and production planning to accommodate the increase in food demand accompanying population growth.

The second issue is environmental problems resulting from the spread of modern agricultural methods. Since the Green Revolution, Asian nations have greatly increased land productivity through the widespread use of modern agricultural methods such as the adoption of highyielding varieties and chemical fertilizers, in response to population growth. However, modern agricultural methods that promote uniform cultivation simplify ecosystems and are harmful to regional biodiversity. This in turn erodes regional characteristics and weakens the ability of regions to adapt to external change, which carries the risk that a major environmental change could result in catastrophic damages.

The third issue is the increase in the demand for biomass energy. While biomass energy is expected to be used more extensively to reduce the use of fossil fuels and lower carbon dioxide $\left(\mathrm{CO}_{2}\right)$ emissions, there are fears that the expansion of cultivated land for the production of biomass energy crops will reduce forest areas. 
The fourth issue is the concern that global warming will lead to a decrease in agricultural productivity. The Fourth Assessment Report from the Intergovernmental Panel on Climate Change (IPCC) examines the impact of global warming on food production and predicts that in low-altitude regions, particularly in tropical regions with dry and rainy seasons, a rise of just one to two degrees Celsius in regional temperatures will lower crop productivity and increase the risk of famine.

To mitigate these issues, it is desirable to develop and disseminate an environmentally advanced model in Asia that takes into consideration the balance of water, food and energy in response to climate change. At the same time, native varieties that are effective, together with native cultivation methods and traditional methods of using local resources that are effective in developing Asian nations, should be actively used. Furthermore, it is necessary to conduct reliable research to find ways to achieve economic betterment through agriculture, and consider the planning and dissemination of technological developments that incorporates the three factors of water, food production and energy at the basin level.

We chose to study the Citarum River Basin, located in the Cianjur Regency in West Java of the Republic of Indonesia. Cianjur is located midway between the cities of Bandung and Bogor, and is situated upstream of the Citarum River Basin. The basin includes the Jatiluhur Dam and Reservoir, which is a reservoir for the capital of Jakarta. The region is a belt for the production of highly palatable rice; however, sediment accumulation and eutrophication have become serious issues in downstream reservoirs, due to the inflow of waste water from urban areas and fertilizer components from hilly upland fields into rivers. In 2009, the MNN (Mother Nature Network) portal for environmental news identified the region as being the most polluted in the world.

To develop and propose an environmentally advanced basin model in Asia, we performed the following tasks: (1) Assess flood risks, drought risks and nitrogen loads; (2) assess the food production potential with remotely sensed data; (3) identify the lands that are suitable for the development of a wide-area assessment model to predict rice growth and yields that takes into consideration weather conditions and variety characteristics; (4) estimate the supply and demand for biomass energy in Indonesia; and (5) propose poverty alleviation policy for farmers as an example of an environmentally advanced basin model in Asia with a focus on water, food and energy.

Figure 1 show the study groups for proposing the environmentally advanced basin model in Asia

\section{Characteristics of the Citarum River Basin}

Recently, severe floods and drought, caused by the global climate change, have occurred in various places around the world. In Asia, in monsoon regions having clear rainy and dry seasons, the water cycle will be accelerated as global warming proceeds, resulting in more intense rainfall and long-term drought. In Indonesia, an increase of food production is needed to accommo- 


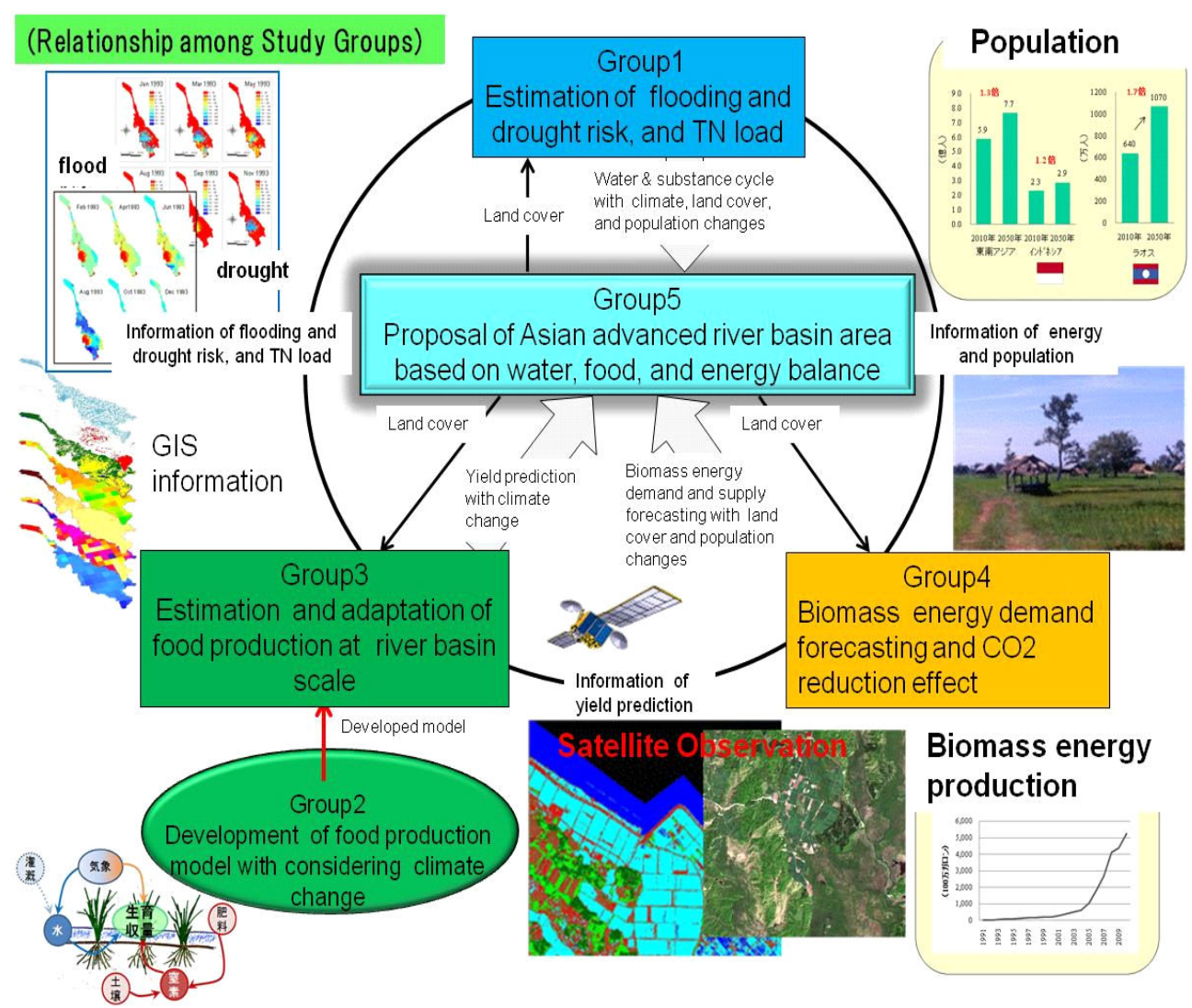

Figure 1. Study groups for proposing the environmentally advanced basin model in Asia

date the growing population. Floods and droughts affect agricultural production directly and indirectly through soil erosion or changes of carbon and nutrient dynamics in the soil. It is difficult to develop more agricultural land in Java, because it is a highly populated island, and thus an irrigation system is necessary to stabilize and increase the production of rice.

The Citarum River is the largest river in West Java. It is $350 \mathrm{~km}$ long and has a catchment area of $6000 \mathrm{~km}^{2}$ (Fig. 2). The annual mean precipitation varies from 1800 to $2800 \mathrm{~mm} /$ year [1]. In this basin, $70 \%$ of the annual precipitation falls in the rainy season, from November to March. Bandung city is located on the upper part of the river, and there are three large dams on the river (Saguling dam upstream, Cirata dam in the middle of the river and Jatiluhur dam downstream). The Citarum River is the most important river in West Java, supplying water for Bandung and Jakarta. Approximately $80 \%$ of the domestic water in Jakarta is withdrawn from the Citarum River downstream of Jatiluhur dam [2]. In the future, climate change may have an undesirable impact on water availability in this basin. Therefore, evaluation of available water resources is quite necessary to manage water resources effectively. 


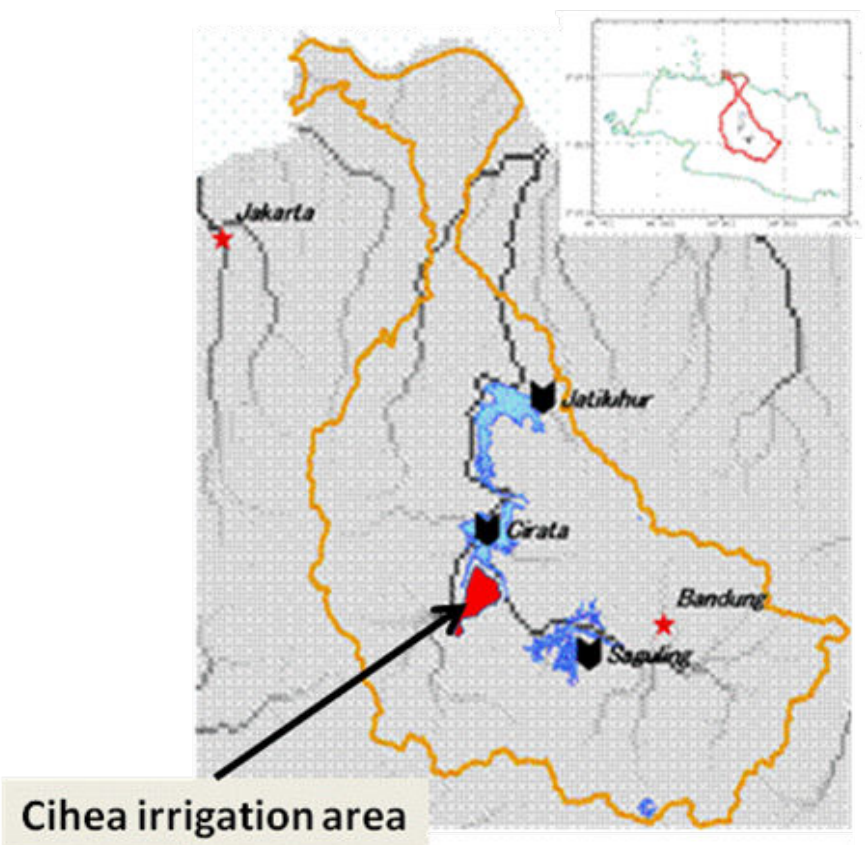

Figure 2. Citarum River Basin

\begin{tabular}{ll}
\hline Classify & (\%) \\
\hline Paddy & 35 \\
Plantation & 25 \\
Forest & 23 \\
Urban, bilt-up & 12 \\
Water & 5 \\
\hline
\end{tabular}

Table 1. Landuse

Table 1 shows land use in the Citarum basin. The main land uses are paddies (35\%), plantations $(25 \%)$, forest $(23 \%)$ and urban build-up (12\%). The Citarum basin is famous as the region's 'breadbasket' because of its rice production. In this region, the annual agricultural production is mainly paddy rice double production in the wet season (Dec. - Mar. and Apr. - Jul.) without use of an irrigation system. Paddy rice could be planted also in the dry season if enough water was available from rivers or water storage facilities. The Indonesian government constructed 
the three big dams (Sagling, Cirata and Jatiluhur) for the purposes of electricity, flood control and water use. As a result, in the downstream area, stable irrigation water is supplied year round. Above the dams, the available water fluctuates annually, and there is not enough water for irrigation during the dry season. This drives farmers to cultivate forest into upland fields to produce money crops, which leads to deforestation, soil erosion and nutrient runoff. This is a big factor in the serious sedimentation and eutrophication in the reservoirs $[3,4]$. To resolve this problem, an effective strategy is needed to alleviate the farmers' poverty, preserve the water quality stored in reservoirs and reduce the runoff from farmlands. The Indonesian government implemented a compensatory system to pay farmers for preserving forest, but the system has not been effective because of the low payment [5]. Furthermore, in the longterm view, compensation will not strengthen farmers' productivity and it will not be effective for dealing with the anticipated population growth in the future. The farmers' poverty must be alleviated in a way that activates and strengthen the existing production system.

\section{Current status of agricultural life in the Citarum River Basin}

We developed a questionnaire targeting 150 households of farmers randomly sampled from 12,447 in total in the Cihea irrigation area, which is in the midstream area of the Citarum River and in which the farming system practiced is typical for this region, to collect information on agricultural life there. The water resource is the Cisokan River, a branch of the Citarum River, and the total irrigation area is 5,484 ha (Fig. 2). The climate is moderate, and paddy rice production isn't limited by the temperature condition during any part of the year. The annual mean rainfall is over $2,000 \mathrm{~mm}$, and $70 \%$ of it falls in the rainy season. The Cisokan River does not have any large water storage capacity in the upstream area, and water intake depends on the natural river discharge. This results in a big seasonal fluctuation of available water from the river, and the irrigation water is not sufficient to grow rice in the dry season. As a typical crop calendar in a year, paddy rice is planted twice in the rainy season (Dec. $\sim$ Mar. and Apr. Jul.) and vegetables such as soy beans and chilies are cultivated extensively in the dry season.

The questions we asked the farmers were designed to gather information about 1 ) the profiles of respondents, 2) respondents' satisfaction with the rice yield and their income from it, and 3) side jobs respondents performed other than rice production.

\section{Profiles}

The average number of household members was 4.3. Figure 3 shows the distribution of harvest area (HA) of each household. HA was defined as follows:

$\mathrm{HA}=\mathrm{CA}$ (for landowners)

$\mathrm{CA} \times 0.5$ (for peasants)

where CA is the actual cultivating area. As shown in Fig. 3, the average CA is 0.26 ha, and $98 \%$ of all households are small farmers (less than 1 ha). 


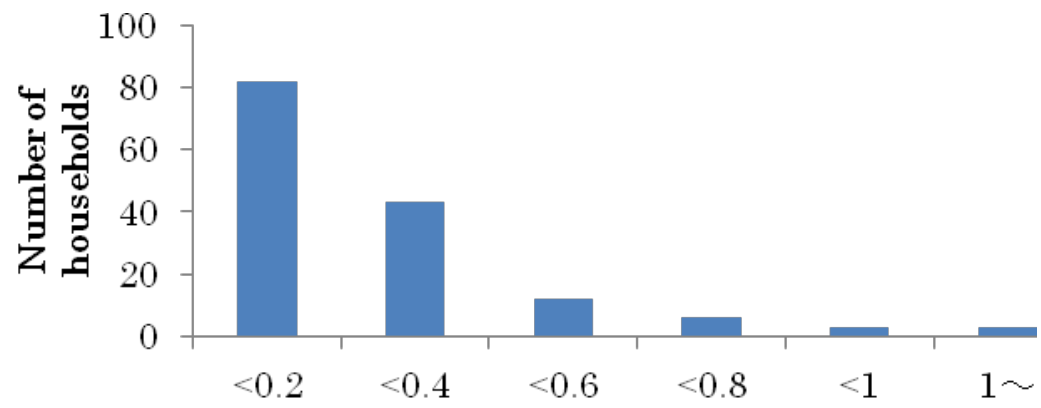

HA (ha)

Figure 3. Distribution of harvest area (HA)

2. Satisfaction with rice yield and income

Table 2 shows the respondents' satisfaction with rice yield and income. The values in the table mean the proportion of respondents who answered 'Yes' to each question. We found that most households are not satisfied with rice yield and the subsequent income. On the other hand, it was implied that the poverty level experienced was not so serious as to worry about how to live their lives, because respondents (= head of family) were modestly satisfied with their income and they indicated they would not move to another place if they could get a higher income.

\begin{tabular}{ll}
\hline \multicolumn{1}{c}{ Question } & Rate of 'Yes'(\%) \\
\hline Do you want to increase rice yield? & 100 \\
\hline Is your income stable every year? & 1 \\
\hline Your income is enough to satisfy your family? & 18 \\
\hline Your income is enough to satisfy yourself? & 58 \\
\hline If you get the higher income, can you move to another place? & 2 \\
\hline
\end{tabular}

Table 2. Satisfaction with rice yield and income

3. Side jobs other than rice production

In all, $64 \%$ of respondents (95 households) have side job other than rice production. In most cases, they worked at farming operations such as transplanting and harvesting in others' fields or ran small shops that deal with sundry articles. More than half of households with side job get higher income from rice production than from the side job (Fig. 4).

Figure 5 shows the relationship between the number of family members (NF) and the annual rice production in dry weight $(\mathrm{P})$. The line shows the amount of self-consumption $(\mathrm{C})$ related to NF. P and C are estimated as follows: 
$\mathrm{P}=\mathrm{HA} \times 3.9(\mathrm{t} / \mathrm{ha}) \times 2$ (harvests/yr)

$\mathrm{C}=\mathrm{NF} \times 100(\mathrm{~kg} /$ capita/yr).

Regardless of NF, many households were plotted around the self-consumption line, and 9 households were plotted under the line, though $\mathrm{P}$ varies widely. Considering the rice production cost $\left(=5.0 \times 10^{6} \mathrm{Rp}\right.$./ha for 1 cultivation), annual income (INC) by the surplus rice (S; $\left.\mathrm{S}=\mathrm{P}-\mathrm{C}\right)$ selling was estimated as follows:

$\mathrm{INC}=\mathrm{S} \times 1.5 \times\left(3.0 \times 10^{3} \mathrm{Rp} . / \mathrm{kg}\right) \times 1,000-\mathrm{HA} \times\left(5.0 \times 10^{6} \mathrm{Rp} . / \mathrm{ha}\right) \times 2($ harvests $/ \mathrm{yr})$

According to estimated income (Fig. 6), more than $70 \%$ of all households had a lower income than the average disposable income of a farmer household in Indonesia (5.8 $\left.\times 10^{6} \mathrm{Rp} ., 2008\right)$. Furthermore, the fact that some households without side jobs cannot get any income by selling surplus rice indicates that job opportunities are scarce in this area.

The questionnaire results indicated the following about the farmers' consciousness and economic situation. First, the income from selling surplus rice (excluding the farmer's consumption) is not enough to alleviate the farmer's poverty, and the chance of a side job that can compensate for the low income is also not enough to alleviate the farmer's poverty. Second, farmers do not want to move to other places, because they like where they currently live. Therefore, we confirm the necessity of countermeasures using the present paddy rice production system.

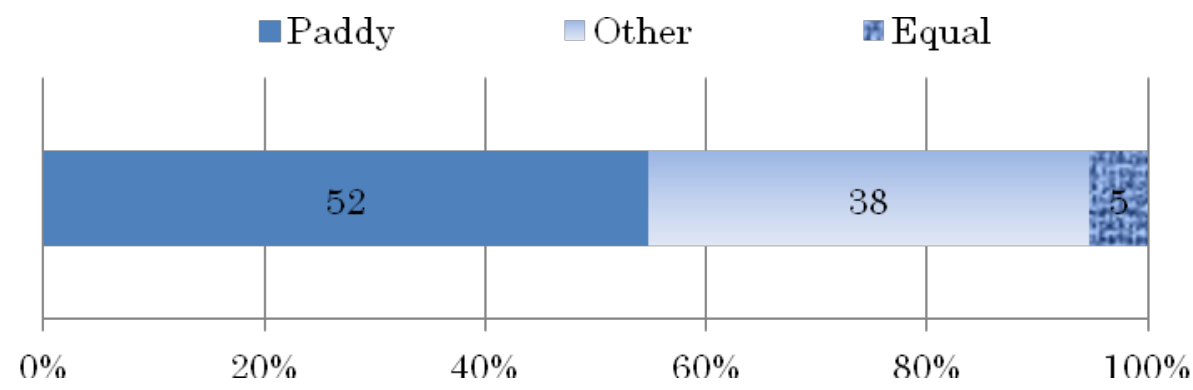

Figure 4. Main income source of households which have side job.

\section{Water resources and nitrogen load}

\subsection{Rainfall -Runoff model}

In the Citarum River Basin, the main water user is the agricultural sector [6]. From 1990 to 2008 , the average available water from the Citarum River was $7.65 \times 10^{9} \mathrm{~m}^{3} /$ year, and the agricultural sector used more than $70 \%\left(5.52 \times 10^{9} \mathrm{~m}^{3} /\right.$ year $)$ of the total. Using this amount of water, farmers can cultivate irrigated paddies 2.1 times per year on average. For food production, especially in paddy fields, much water is needed, and that is strongly affected by natural 


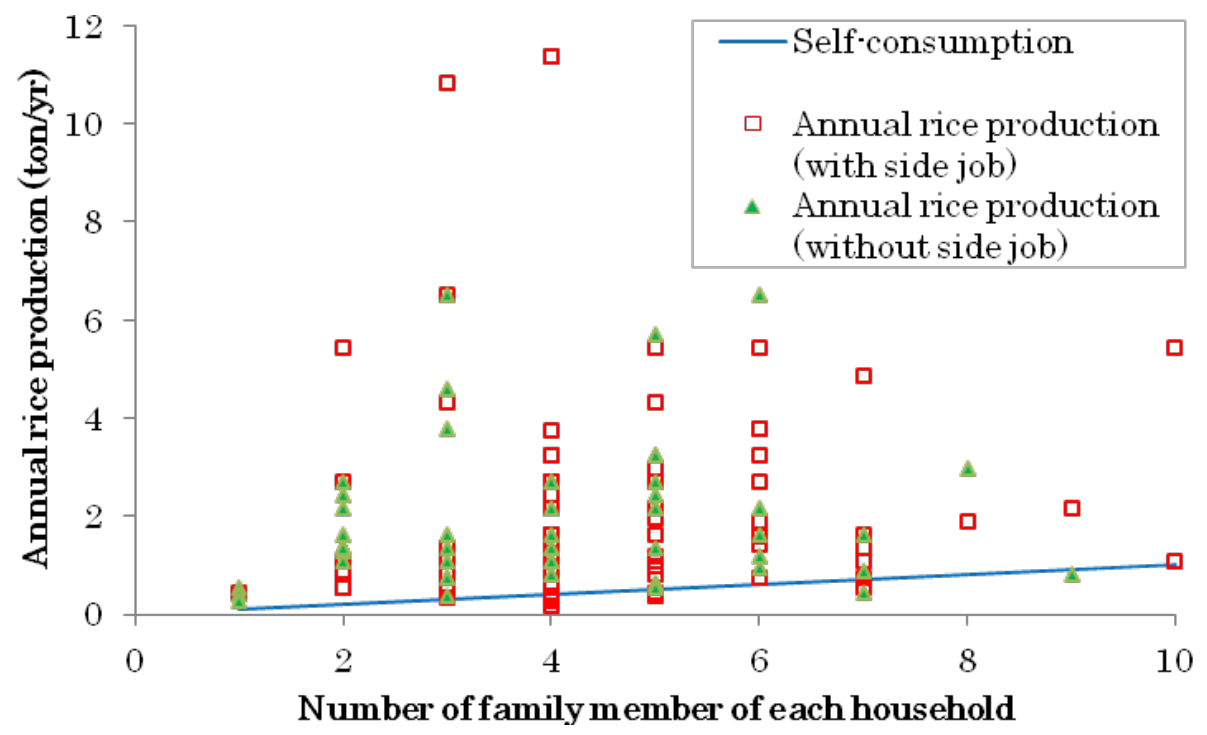

Figure 5. Relationship between number of family member and annual rice production.

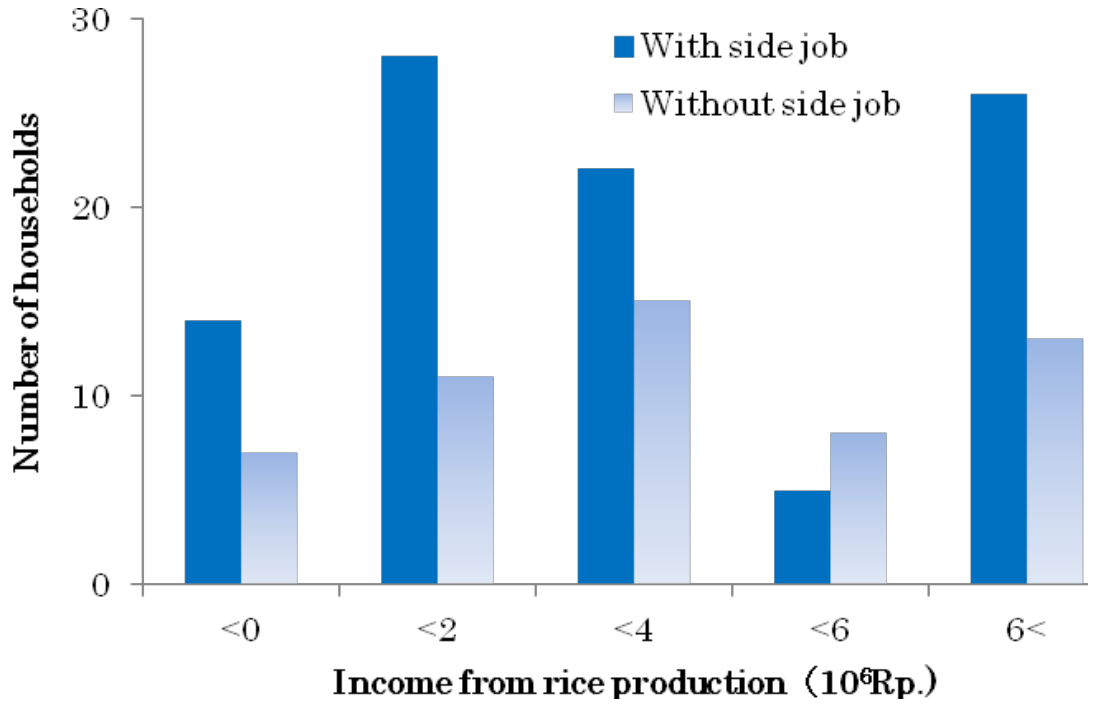

Figure 6. Histogram of income of each household from rice production.

weather conditions. Therefore, to evaluate the future potential of irrigation supply, we developed a distributed water cycling model and used it to analyze the water balance in the Citarum River Basin. For the rainfall-runoff analysis, we used TOPMODEL, a distributed type model. A distributed model can include spatial distribution of topography, land use and soil 
characteristics. Therefore, this type of model is widely used for hydrological characteristics analysis, water management, water quality analysis and forecasting.

TOPMODEL was proposed by Beven and Kirkdy [7] and is based on the contributing area concept in hill slope hydrology. This model is based on the exponential transmissivity assumption that leads to a topographic index $\ln (a /$ To/tan $b)$. To is the lateral transmissivity under saturated conditions, $a$ is the upstream catchment area draining across a unit length and $b$ is the local gradient of a ground surface. TOPMODEL consists of three soil layers, the root zone, unsaturated zone and saturated zone (Fig.7). Water content (WC) of the root zone and unsaturated zone is calculated by distributed parameters, and WC of the saturated zone is normally calculated by lumped parameters. However, in this study, WC of the saturated zone is also calculated by distributed parameters. Figure 7 shows the TOPMODEL structure. TOPMODEL needs only 3 parameters, so this model is easy to link with GIS data (for details, see $[8,9])$. A dam operation model was combined with TOPMODEL to evaluate the validation of water storage in the reservoir.

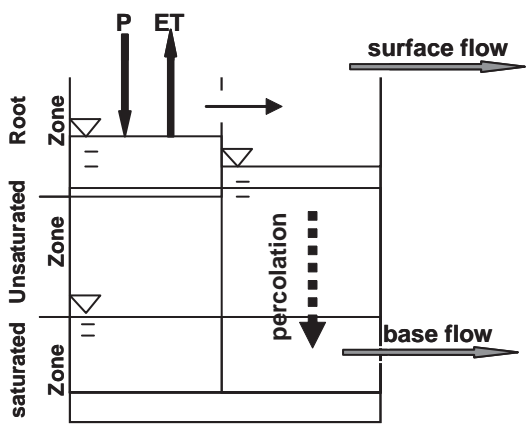

Figure 7. TOPMODEL structure.

\subsection{Evaluation of available water resources in the future}

For forecasting, we used the Model for Interdisciplinary Research on Climate (MIROC5) with the spatial resolution of 1 degree, which is a general circulation model (GCM), and the generated data was used after bias correction. Figure 8 shows the annual mean air temperature and rainfall amount from 2006 until 2100 of MIROC5(rcp8.5) output at Bandung city. The model predicts that the air temperature will increase gradually more than 3 degrees during approximately 100 years. The trend of annual rainfall will not change significantly. For example, the 10-year average rainfalls are $2193 \mathrm{~mm} /$ year (1996 to 2005), $2170 \mathrm{~mm} /$ year (2021-2030) and $2258 \mathrm{~mm} /$ year (2046-2055).

Figure 9 shows decadal rainfall and calculated river discharge at the Cirata dam station in the cases of (a) 1996-2005 and (b) 2046-2055. In 2046-2055, rainfall intensity became low, with rain falling more equally throughout the year and with middle amounts of rainfall continuing for longer times compared to 1996-2005. The river discharge alters a great deal in response 


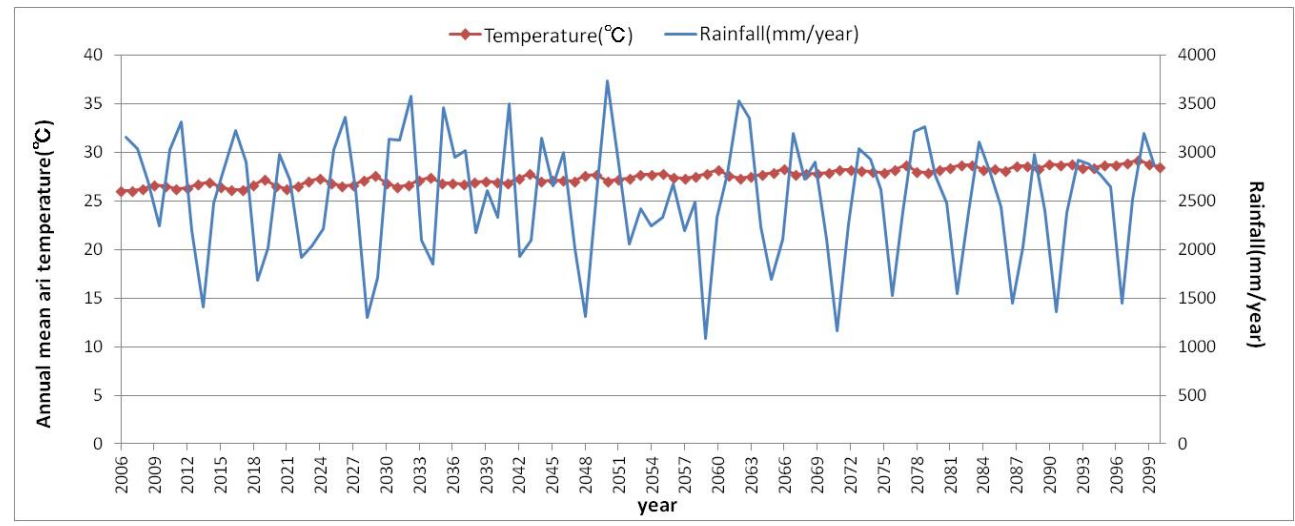

Figure 8. Annual mean air temperature and rainfall amount from 2006 until 2100 of MIROC5 (rcp8.5).

to such rainfall changes. For example, the drought period during which the river discharge was less than $100 \mathrm{~m}^{3} / \mathrm{s}$ in 1996-2005 was 632 days/10 years, but in 2046-2055, it increased to 881days/10years. This increase in the drought period was also affected significantly by evapotranspiration. In this calculation, potential evapotranspiration was calculated from air temperature data by using the Thornthwait method. The runoff ratio, which is the ratio of total river discharge per total rainfall amount, decreased from 0.65 in 1996-2005 to 0.59 in 2046-2055. In the case of flooding (more than $500 \mathrm{~m}^{3} / \mathrm{s}$ ), the frequency increased from 2 times in 1996-2005 to 5 times in 2046-2055. These results show that water will become difficult to obtain in the future, and water scarcity and competition among the water users will become severe.

\subsection{Nitrogen loads from point sources}

High-quality fresh water is limited in quantity, and there is a need for comprehensive water management. Therefore, control of water pollution has become important in many developing countries. In the case of the Citarum River, domestic water for Jakarta and Bandung city has problem of quality and quantity, so water quality assessment is quite important [10]. Although nitrogen is essential for living organisms as an important constituent of proteins, excess enriched nutrients may cause eutrophication of water bodies, especially in lakes or reservoirs. Figure 10 shows the observed total nitrogen (T-N) concentration at Nanjung station, which is located a little bit upstream from Saguling reservoir. The T-N value sometime exceeds $10 \mathrm{mg} /$ L. At Nanjung station, the measurement is affected by waste water from Bandung city and drained water from upstream agricultural fields that flow into the Citarum River.

In the Citarum River, hydrological and water quality data were very limited because of the low frequency of measurements and the fact that data are only observed at a few main stream points. Therefore, it is difficult to evaluate the distribution of the nitrogen pollution load, especially from non-point sources. However, nitrogen loads from point sources such as human and livestock origin can be estimated roughly. Food and Agriculture 


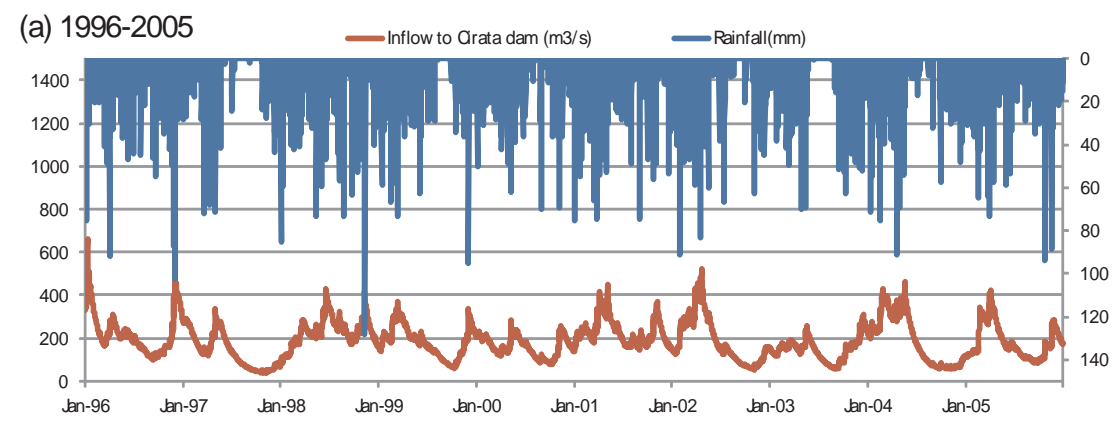

(b) 2046-2055

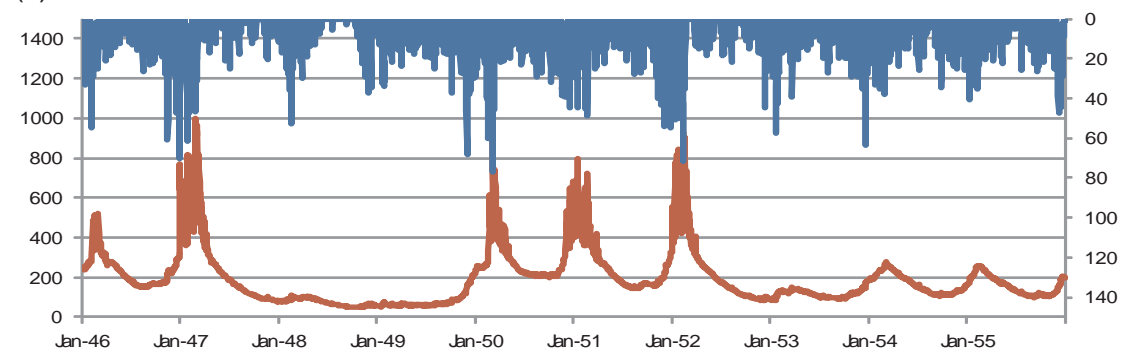

Figure 9. Decadal rainfall and calculated river discharge in 2000 and 2050.

Total Nitrogen ( $\mathrm{mg} / \mathrm{L}$ )

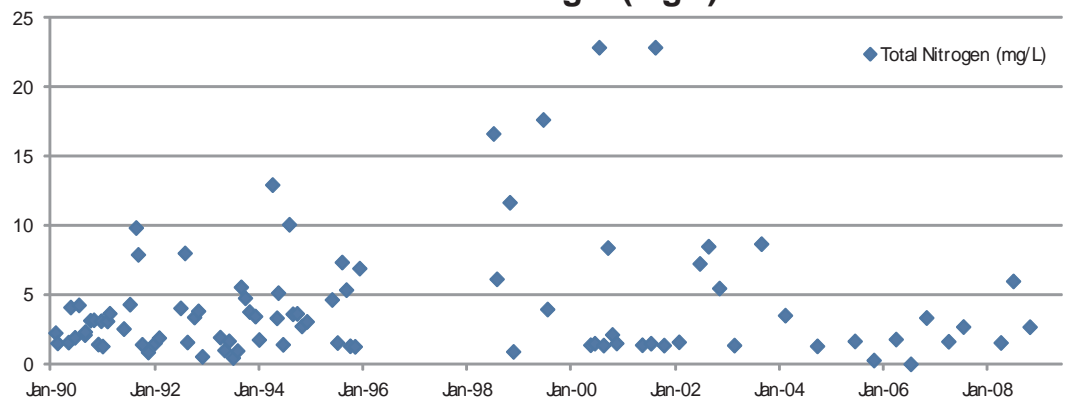

Figure 10. Observed total nitrogen concentration from 1990-2008.

Organization, FAO [11] spatial livestock density data (5-km resolution) and pollution load factors data from Kunimatsu and Muraoka [12] were used for calculation. Figure 11 shows spatial distribution of nitrogen loads from each source in the Citarum basin. Bandung is a highly populated city, so the pollution load is rather large compared to that of a rural area. Table 3 shows annual total nitrogen loads from each source. Humans (54.9\%) and chickens $(33.8 \%)$ were estimated to be the main sources of the nitrogen load in the Citarum 
River. In many developing counties, waste water from urban build-up is directly drained into river without treatments. In rural areas, wastes from livestock or human livings are stored in agricultural fields or other soil layers. Such wastes decompose slowly. Therefore, for pollution control or management, a nutrient dynamic model in the soil or water bodies should be developed and applied.

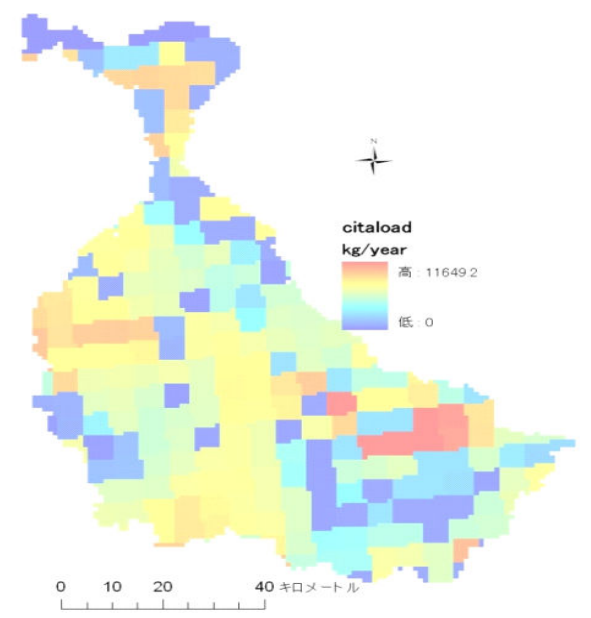

Figure 11. Distribution of nitrogen loads in Citarum river basin.

\begin{tabular}{crr} 
& Load(kg/year) & rate $(\%)$ \\
\hline Pig & $1,081,605$ & 1.7 \\
\hline Cattle & $2,581,953$ & 4.1 \\
\hline Chicken & $21,461,371$ & 33.8 \\
\hline Goat & $3,511,724$ & 5.5 \\
\hline Human & $34,927,088$ & 54.9 \\
\hline
\end{tabular}

Table 3. Nitrogen loads frompoint sources

\section{Estimation of rice yield from remotely sensed data}

\subsection{Remote sensing for agriculture}

Environmental conservation and food production are critical issues that people in every country must make their best efforts to solve. Remote sensing agricultural research, especially related to rice production and rice field management, is very important for Asian countries, 
because rice is the staple food for the people and, on the other side, Asian agriculture frequently suffers from heavy losses caused by meteorological events. Considering these matters, it is a good idea to develop an efficient rice cultivation support system based on a concept of precision agriculture that can effectively increase rice production and also realize environmental conservation.

As shown in Table 4, remote sensing using satellites has been tried in a variety of fields and now is considered to be an excellent method for agriculture crop identification [13-15].One of the valuable outcomes to be expected from the remote sensing research for agriculture is to create crop yield models through the assessment of various crop growth variables [16]. For this assessment, it is very important to clarify the quantitative relationship between the remote sensing data and the variables related to crop growth [17]. The remote sensing data to be obtained from crops represents the growing conditions of the crops, which allows the estimation of crop yield [18].

In previous studies of the agricultural remote sensing research in Indonesia, the yield of rice was estimated by the reflectance data of Landsat ETM+ data and MODIS data $[19,20]$. It was reported that the Ratio Vegetation Index (RVI) was the best vegetation index for both early detection of water deficiency and also distinguishing different crop conditions such as healthy and water stressed crops [21].

\begin{tabular}{ll}
\hline \multicolumn{1}{c}{ Classification } & \multicolumn{1}{c}{ Item } \\
\hline Land & $\begin{array}{l}\text { Land use, discrimination of crops, crop acreage, barren farmland, denudation/landslides, } \\
\text { melting of snow, floods, } \\
\text { damage due to disaster }\end{array}$ \\
\hline Crops & $\begin{array}{l}\text { Growth conditions, yield estimation, contents and quality, } \\
\text { estimating harvest season, outbreaks of agricultural pests, assessing disaster/damage }\end{array}$ \\
\hline Soil/ environment & $\begin{array}{l}\text { Organic matter content, moisture characteristic, gravel distribution, soil classification, } \\
\text { temperature distribution, evapotranspiration, suitability of land }\end{array}$ \\
\hline Comprehensive application & $\begin{array}{l}\text { Land productivity, land improvement, agricultural field management, growth } \\
\text { management, farming plans, preparedness for disaster/damage }\end{array}$ \\
\hline
\end{tabular}

Table 4. Uses of remote sensing

\subsection{Methodology}

In this study, to assess the feasibility of the estimation of rice yield using remotely sensed data, we investigated the relationship between annual rice production from the agricultural statistical data and cumulative Leaf Area Index (LAI) derived from MODIS LAI 8 days composite data in West Java, Indonesia. The study was conducted in 5 sub-districts (Kecamatan Bojongpicung, Ciranjang, Karangtengah, Sukaluyu and Mande) located in the northeast area of Kabupaten Cinajur, West Java, Indonesia (longitude $106^{\circ} 21^{\prime} \mathrm{E}-107^{\circ} 22^{\prime} \mathrm{E}$, latitude $6^{\circ} 42 S^{-} 7^{\circ} 25^{\prime}$ S) (Fig. 12). 
The southern part of the mainland West Java has mountains with more than 1,500 m height, although the mountainous area is only $9.5 \%$ of the total West Java. The central part is a slope of the mountains with a height from 10 to $1,500 \mathrm{~m}(36.48 \%)$, and the northern part is a large plain with a height from 0 to $10 \mathrm{~m}(54.03 \%)$. Regarding the farming in West Java, $22.89 \%$ is mixed farming fields, $20.27 \%$ is rice fields and $17.41 \%$ is estate crops fields. Only $15.93 \%$ of the total area of West Java is forested.

West Java is a major province for agriculture production in Indonesia, but one problem is that the total amount of actually produced crops is less than that of the estimation made by the government. In 2012, the target production amount of rice set by West Java is 12.5 million ton, which is much different from the estimation. Much room remains for improvement of the production amount.

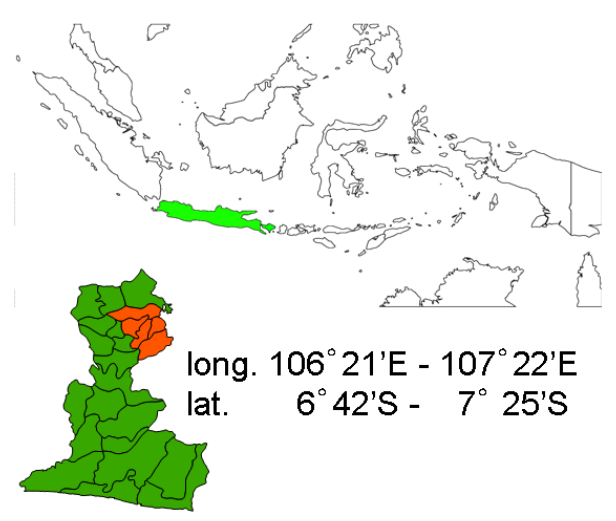

Figure 12. Study site.

In this study, the following data were used for analysis:

1. MODIS/Terra+Aqua Leaf Area Index 8-day L4 Global 1km SIN Grid V005 was collected from October 2001 to September 2008 (276 sets of composite data),

2. SPOT5 satellite (HRG-X) data was acquired on February 20 and July 10, 2011,

3. TERRA satellite (ASTER) data was acquired on May 29,

4. Administrative boundary Geographic Information Systems (GIS) data,

5. Agricultural statistics data from 1996 to 2008 published by Badan Pusat Statistik (BPS).

Figure 13 shows the procedure for analysis. First, the LAI, the SPOT data and the ASTER data were rectified using the administrative boundary GIS data by the nearest neighbor resampling algorithm with use of the selected ground control points. Second, a supervised classification was applied to these rectified images to distinguish the paddy fields, and the mask file of paddy fields was created. Data on cumulative LAI values of paddy fields from October 2001 to September 2008 were calculated, and the data was added to the GIS administrative boundary 
data. Finally, the tabulate area analysis was executed using the LAI data and the agricultural statistic data to analyze the seasonal trend of LAI and the relationship between the annual rice production and LAI.

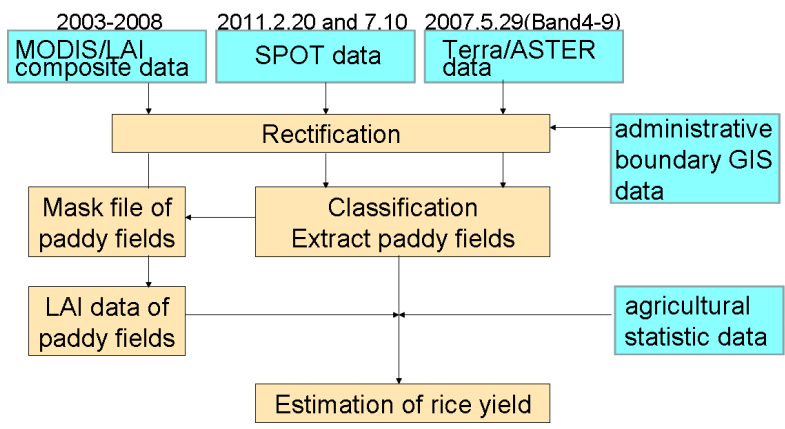

Figure 13. Procedure of image analysis.

\subsection{Results and discussion}

The seasonal trend of averaged LAI in all sub-districts (Kecamatan) is shown in Fig. 14. There are three minimum values in a year, which are in March, July and December. These seasons correspond to the harvesting season of the rice crop around the test site. In some areas of the test site the vegetation crops are cultivated from August to November, during which period the irrigation water supply is insufficient because of the dry season. This is why the shape of the LAI peak is not clear during this period.

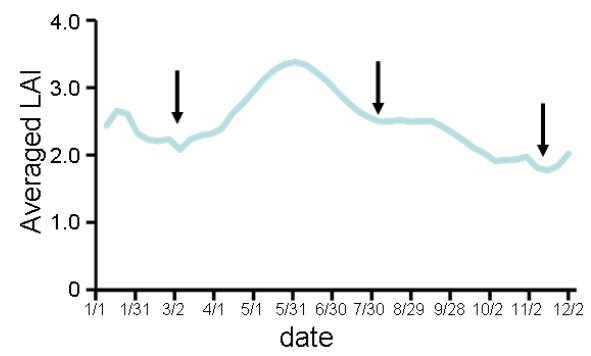

Figure 14. Seasonal trend of averaged LAl of around the test site.

Table 5 shows the relationship between the cumulative LAI of each month and the annual rice production. The result shows significant positive correlation between the annual rice production and the cumulative LAI of each month except for February and December. The correlation coefficients in January, May and September, the months before the harvesting season, respectively, are relatively high against other months. These months are the $30^{\text {th }}$ day or $40^{\text {th }}$ day after 
transplanting the rice seedlings. The situation in these months is that paddy fields are covered with green crops, and so the water surface of the paddy field is closed.

\begin{tabular}{|c|c|c|c|c|c|c|c|c|c|c|c|c|}
\hline sub-district & Jan & Feb & Mar & Apr & May & Jun & Jul & Aug & Sep & Oct & Nov & Dec \\
\hline All & $0.558 * *$ & 0.353 & $0.372 *$ & $0.459 *$ & $0.603 * *$ & $0.657 * *$ & $0.529 * * *$ & $0.671 * * *$ & $0.668 * * *$ & $0.604 * * *$ & $0.569 * * *$ & 0.217 \\
\hline Bojongpicung & -0.578 & 0.106 & $-0.831 *$ & -0.074 & 0.380 & 0.516 & -0.266 & 0.040 & 0.192 & -0.683 & 0.201 & -0.570 \\
\hline Ciranjang & 0.120 & 0.115 & -0.648 & -0.616 & 0.542 & 0.396 & -0.398 & -0.164 & 0.488 & -0.232 & -0.625 & -0.740 \\
\hline Karangtengah & 0.396 & 0.023 & $-0.916 *$ & -0.141 & 0.755 & -0.031 & -0.444 & 0.261 & 0.587 & 0.648 & -0.485 & $-0.878 *$ \\
\hline Sukaluyu & 0.133 & -0.196 & $-0.887 *$ & -0.114 & 0.533 & -0.135 & -0.378 & -0.141 & 0.268 & 0.237 & -0.758 & -0.737 \\
\hline Mande & -0.178 & 0.169 & -0.660 & -0.015 & 0.580 & -0.412 & -0.027 & 0.578 & 0.778 & 0.294 & 0.048 & -0.805 \\
\hline
\end{tabular}

Table 5. Relationship between cumulative LAI of each month and the annual rice production

On the basis of data from 1996 to 2008, we investigated the relationship between the actual planted acreageand theannual production amount, and we found significant positive correlation in every sub-district. $(\mathrm{n}=13, \mathrm{p}<0.05)$ (Table 6). Based on these results, the significant positive relationship between the cumulative LAI and the annual production in these months was found, because we could estimate the actual planted acreage from the cumulative LAI data.

\begin{tabular}{cccccc}
\hline All sub-districts & Bojong picung & Ciranjang & Karangtengah & Sukaluyu & Mande \\
\hline $0.781^{\star *}$ & $0.683^{*}$ & $0.637^{\star}$ & $0.854^{*}$ & $0.775^{\star *}$ & $0.970^{\star *}$ \\
\hline
\end{tabular}

Table 6. Correlation coefficient of between actual planted acreage and the annual rice production

The relationship between the cumulative LAI of January, May and September and the annual rice production is shown in Fig.15. There is a positive correlation between the cumulative LAI of all sub-districts and the annual rice production $(\mathrm{r}=0.664, \mathrm{p}<0.01)$. Moreover, the correlation coefficient gets higher when limited to three sub-districts where the irrigation ratio is more than $80 \%(\mathrm{r}=0.866, \mathrm{p}<0.01)$.

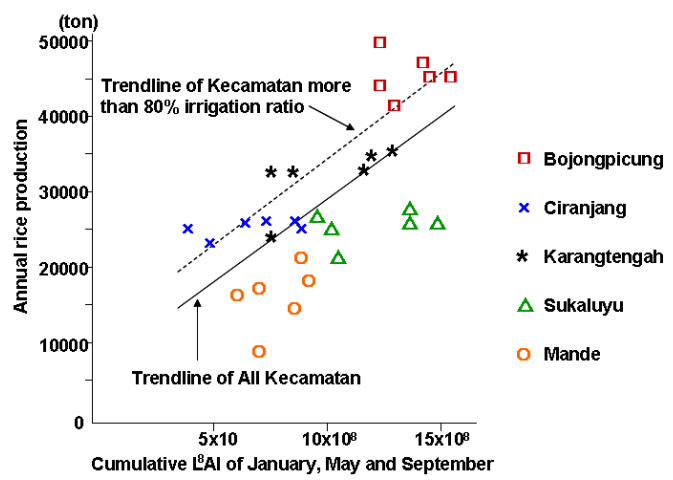

Figure 15. Relationship between the cumulative LAI of January, May and September and the annual rice production. 
It was possible to estimate the annual rice production of 2008 using the cumulative LAI of January, May and September from 2003 to 2007. This study indicates that the cumulative LAI of remotely sensed data is applicable to the estimation of rice production amount over a wide area, and the creation of each estimation equation for the irrigated paddy fields and the rainfed paddy fields will contribute to the improvement of the estimation accuracy of the annual rice production.

\section{Toward the development of a simulation model to evaluate geographical distributions of rice growth and yield}

\subsection{Use of advanced remote sensing for rice production}

As the previous section suggests, satellite-based remote sensing is quite useful for obtaining information about crop production. However, the estimation of rice production in the previous section was based on the course relationship between accumulated LAI and rice production, and the relationship lacks crop ecological mechanisms. Accordingly, if the crop ecological processes are incorporated into the relationship, the accuracy of estimation of crop production should improve. Such processes could estimate not only the production but also the cause for the production by inverse calculation. If the inverse calculation can suggest the constraints of production, e.g., soil fertility, water management and cultivar, the suggestions will be quite useful for improving the productivity and developing a strategy for the future. To incorporate crop ecological processes into the relationship between remote sensing data and crop production, we have been developing a simulation model combined with remote sensing (SIMRIWRS) [22]. This section explains the concept of the simulation model and reports the present status of development.

\subsection{The concept of a simulation model combined with remote sensing}

The architecture of our simulation model, SIMRIW-RS was derived from SIMRIW-Rainfed, which was developed on the basis of SIMRIW [23] to simulate variation in rice productivity at farmers' paddy fields in Northeast Thailand [24]. Since SIMRIW is widely adapted to simulate rice productivity under a future climate scenario $[25,26]$, its derivative simulation models are also expected to be able to simulate that.

To parameterize for crop growth by remote sensing data, smaller numbers of parameters in the simulation model are better. On the other hand, the simulation model is required to evaluate variation in productivity among farmers' fields. Evaluation of cultivar difference is also required to select optimum cultivars to improve the productivity and to develop a strategy of cultivar breeding for adaptation to climatic change in the future. These requirements indicate that the simulation model should have the minimum number of field and cultivar parameters that evaluate field-to-field and cultivar-to-cultivar variability.

To simulate phenological development of rice, the same functions in SIMRIW are applied. Namely, the phenology is indexed by a Developmental Index (DVI): DVI $=1$ for panicle 
initiation, DVI = 2 for heading and DVI = 3 for maturity [27]. DVI progress is expressed by the accumulation of the daily progress rate of development (DVR), which is expressed by functions of day length and daily average temperature. Although these functions need some cultivar parameters, the parameters can be estimated based on the database of parameters [28] and adjusted by the present cultivation schedule. If phonological development can be distinguished by satellite-based remote sensing, the parameters can also be estimated. However, since the distinguishing is not very accurate yet, the estimation of cultivar parameters for DVI by remote sensing is not under consideration in this study.

Plant growth and yield formation are expressed by four functions (Table 7). Plant growth is driven by nitrogen uptake (Nup), which is expressed by a function with a field parameter for nitrogen supply and a cultivar parameter for nitrogen uptake ability. Leaf area (LA) expansion is a function of Nup and DVI with two cultivar parameters: the LA expansion rate and the maximum LAI. Since the maximum LAI is set as a constant value $(=7)$, a substantial number of parameters for LA expansion is one. Dry matter (DM) is a product of solar radiation intercepted by LA and a cultivar parameter radiation conversion efficiency, which is varied with Nup per LA. Grain yield is obtained by DM multiplied with a cultivar parameter, the harvest index. Consequently, one field parameter and four cultivar parameters must be determined to simulate rice growth and yield.

\begin{tabular}{ll}
\hline Function & Note $^{11}$ \\
\hline
\end{tabular}

(1) Phenological development

$$
\begin{aligned}
& D V I=\Sigma D V R \\
& D V R=f\left(D_{l}, T_{\text {ave }}\right)
\end{aligned}
$$

Nakagawa and Horie (oxox); $D_{\text {: }}$ day length; $T_{\text {ave }}$ : daily average temperature; cultivar parameters are offered

(2) Nitrogen uptake (Nup)

$$
\begin{array}{ll}
\Delta N u p=f\left(a_{1}, \beta_{1}, T_{\text {ave, }} D V I\right) \quad & a_{1}: \text { nitrogen supply } \\
& \beta_{1}: \text { nitrogen uptake ability }
\end{array}
$$

(3) Leaf area (LA) expansion

$$
\begin{array}{ll}
\Delta L A=f\left(\beta_{2}, \beta_{3}, \Delta N u p, D V I\right) \quad & \beta_{2} \text { : Leaf area expansion rate } \\
& \beta_{3}: \text { Maximum LAI ( }=7 \text { in this study) }
\end{array}
$$

(4) Dry matter (DM) production

$$
\Delta D M=f\left(\beta_{4}, S_{n}, \text { Nup }, L A, D V I\right)
$$

$S_{n}:$ Solar radiation

$\beta_{4}$ : Radiation conversion efficiency

(5) Yield formation

$$
\text { Yield }=f\left(\beta_{5}, D M\right)
$$

$\beta_{5}:$ Harvest index

1) $\mathrm{a}$ : field parameter; $\beta$ : cultivar parameter.

Table 7. List of functions in the simulation model [22] 


\subsection{Determination and validation of default parameters in the simulation model}

To test model performance, we determined default parameters in the simulation model based on a field experiment. The field experiment was conducted in Kyoto using three different types of field. In one of the three types of field, three kinds of fertilizer treatment were tested, and thus five nutritional environments were tested. Six different types of cultivar were planted in each environment (Table 8).

Field $\left(\alpha_{1}\right)$ and cultivar $\left(\beta_{1}\right)$ parameters for Nup were determined statistically based on the relationship between Nup by plant and accumulated effective average air temperature. The other three cultivar parameters $\left(\beta_{2}, \beta_{4}\right.$ and $\left.\beta_{5}\right)$ were optimized by a simplex method, one of the nonlinear least squares methods, based on the observed data.

The obtained parameters are shown in Table 8. The parameters seem to express the field and cultivar characteristics. Based on the parameters, the simulation model well explained fieldto-field and cultivar-to-cultivar variation in Nup, LA, DM and yield (Fig. 16), suggesting that this use of one field parameter and four cultivar parameters was adequate for the purpose.

\begin{tabular}{lcccccc}
\hline \multirow{2}{*}{ Field parameter } & \multicolumn{3}{c}{ Kyoto Univ. Expt. field } & & \multicolumn{2}{c}{ Conseq. Un-fert. Field } \\
\cline { 2 - 7 } & Un-fert. & Less fert. & Standard & & 6 yr conseq. & 59 yr conseq. \\
\hline \multicolumn{1}{c}{$\boldsymbol{\alpha}_{1}$ : N supply } & $\mathbf{0 . 0 0 4 5}$ & $\mathbf{0 . 0 0 4 9}$ & $\mathbf{0 . 0 0 7 6}$ & & $\mathbf{0 . 0 0 3 4}$ & $\mathbf{0 . 0 0 1 9}$ \\
\hline & Nipponbare & Kasalath & Bei Khe & Takanari & B6144F & Baniasahi \\
\hline$\beta_{1}:$ NUA & 0.0043 & 0.0048 & 0.0042 & 0.0054 & 0.0044 & 0.0037 \\
$\beta_{2}:$ LER & 3.3 & 4.9 & 5.2 & 3.1 & 5.9 & 5.0 \\
$\beta_{4}:$ RUC & 0.46 & 0.66 & 0.64 & 0.49 & 0.69 & 0.58 \\
$\beta_{5}:$ HI & 0.43 & 0.46 & 0.39 & 0.48 & 0.45 & 0.44 \\
\hline
\end{tabular}

fert.: fertilizer; conseq.: caonsequence; NUA: nitrogen uptake ability; LER: leaf expansion rate; RUC: radiation conversion efficiency; HI; harvest index.

Nipponbare: improved japonica in Japan; Kasalath: traditional indica in India; Bei Khe: traditional indica in Cambodia; Takanari: improved indica in Japan; B6144F: improved indica in Indonesia; Baniasahi: traditional japonica in Japan.

Table 8. List of default field and cultivar parameters in the simulation model. Values were determined based on the field experiment

\subsection{Remote sensing technique for optimizing field and cultivar parameters in the simulation model}

As mentioned in previous section, the simulation model can do a good job of estimating rice growth when one field parameter and four cultivar parameters in the simulation model can be set appropriately. Remote sensing will be helpful for optimizing these parameters using a simplex method on the regional and global scale. While there are several procedures to optimize the above-mentioned parameters using remote sensing, that shown in Fig. 17 was 

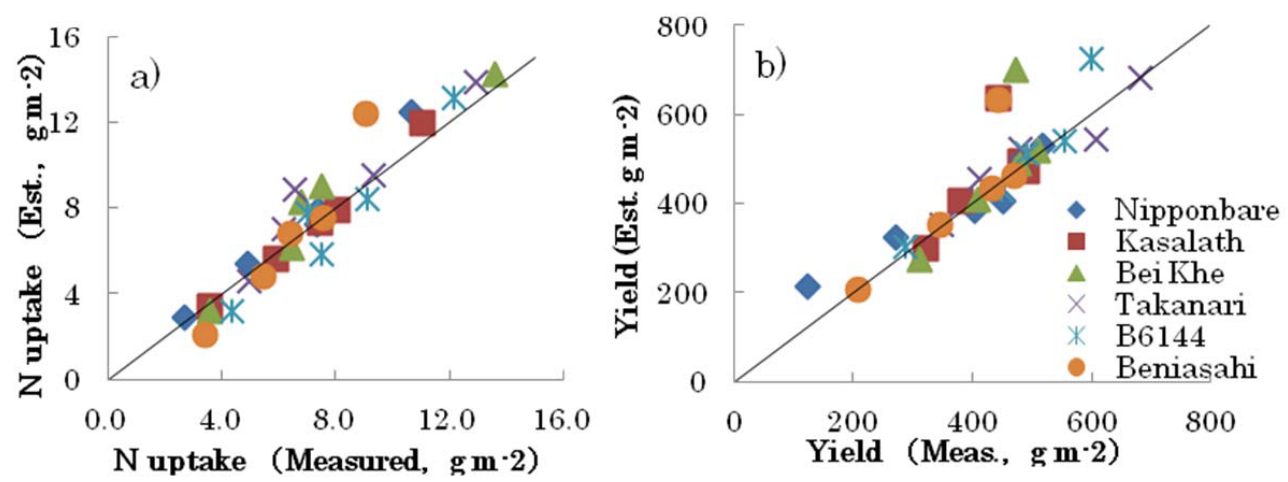

Figure 16. Comparison between measured and estimated nitrogen (N) uptake (a) and yield (b). Six different cultivars tested in the five different nutritional environments.

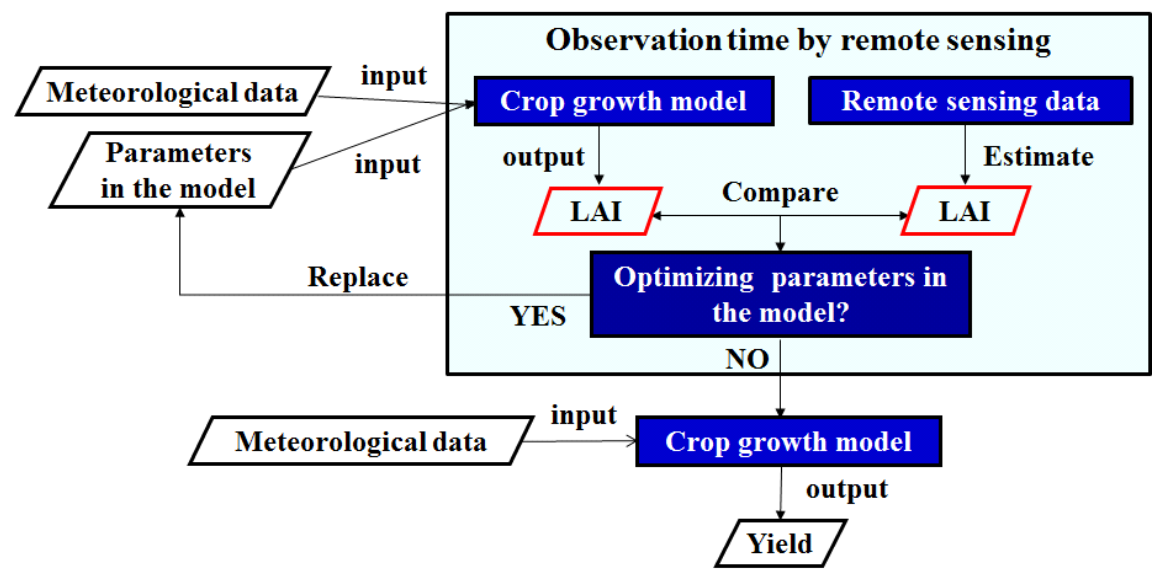

Figure 17. Concept of optimizing field and cultivar parameters in the simulation model using remote sensing data.

selected for this study. This figure shows that these parameters will be optimized by comparison between LAI simulated by the model and the one estimated by remote sensing data. This figure indicates that LAI is a key factor and that the estimation accuracy of LAI obtained from remote sensing data is the most important source of information for optimizing these parameters in the model.

When remote sensing is used to monitor crop LAI, there are two methods to determine the desired information. One is to use the regression expression obtained from the relationship between vegetation index derived from spectral reflectance at the crop canopy level and LAI measured by field experiment, and another is to use the inversion method of the radiative transfer model with spectral reflectance at the crop canopy level. Generally, at the satellite (or airborne) level, it is more difficult to apply the inversion method to monitor crop LAI than the 
regression expression obtained from the relationship between vegetation indices derived from spectral reflectance and LAI measured by field experiment. Therefore, the method using vegetation indices has been widely used to monitor crop LAI on the regional and global scale. Popular vegetation indices for monitoring crop LAI include the Normalized Difference Vegetation Index (NDVI), the Soil Adjusted Vegetation Index (SAVI) and the Enhanced Vegetation Index (EVI). The most famous index is the NDVI [29]. The value of the NDVI increases with an increase in the amount of crop leaves. Although the NDVI was widely used to estimate crop LAI, it was reported that the value of NDVI saturated when plants at grew closely or when the plant canopy structure was complex and consisted of multiple layers [30]. The EVI was developed to solve this problem of the NDVI [31]. The EVI can be applied to the situation when plants at the observed place have high density or a complicated structure, and this index reduces the adverse effects of environmental factors such as atmospheric conditions and soil background [32]. The SAVI is also an improved version of the NDVI. The SAVI is the index that considers the effect of soil background on the NDVI [33].

The above-mentioned indices have been used for plant monitoring. Generally, the regression expression obtained from the relationship between vegetation indices derived from remote sensing data at the crop canopy level and measured LAI at the ground level have been widely used to monitor plant LAI. However, these regression expressions were not derived based on a radiative transfer process of reflectance dependent on crop growth. Namely, these regression expressions have the possibility of changing from year to year and place to place. Here, a new vegetation index for monitoring plant LAI developed by the authors is described. This index was derived from the radiative transfer process of reflectance that is dependent on crop growth. The new vegetation index is based on the results reported in Oki et al. [34] and described both the accuracies of mixel (mixed pixel) decomposition when spectral reflectance at visible wavelength bands was used and when spectral reflectance from visible to near-infrared wavelength bands was used. In general, the reflectance value from a mixel is expressed as the linear combination of the reflectance values of the target and other objects, as follows:

$$
\begin{aligned}
& \mathbf{p}=\alpha \mathbf{m}+(1-\alpha) \mathbf{n} \\
& \mathbf{p}=\left(\begin{array}{c}
p_{1} \\
\vdots \\
p_{N}
\end{array}\right), \quad \mathbf{m}=\left(\begin{array}{c}
m_{1} \\
\vdots \\
m_{N}
\end{array}\right), \quad \mathbf{n}=\left(\begin{array}{c}
n_{1} \\
\vdots \\
n_{N}
\end{array}\right)
\end{aligned}
$$

where $\mathrm{p}, \mathrm{m}$ and $\mathrm{n}$ are vectors of measured spectral reflectance, pure reflectance of the target object and noise, respectively. Here, $\alpha$ is the fraction of the target object area, and $N$ is the number of wavelength bands. To estimate the fraction of the target object area, Oki et al. [34] developed an improved matched filter method that estimates the fraction of the target object area by calculating the degree of similarity of wave profiles of measured spectral reflectance to pure spectral reflectance of a target object. According to Oki et al. [34], using spectral reflectance only in the visible region is more suitable for precise detection of the fraction of the target object area than is using spectral reflectance at the visible and near-infrared wavelength 
bands. Reflectance at the visible wavelength band is insusceptible to multi-scattering in a canopy, because reflectance and transmittance of this wavelength of leaves are small. Therefore, $\alpha$ calculated using only reflectance at visible regions reflects information about the crop canopy surface. On the other hand, reflectance and transmittance at near-infrared wavelength bands of leaves are larger than those at visible wavelength bands. Therefore, the accuracy of $\alpha$ degrades because the influence of multi-scattering in a canopy is included in $\alpha^{\prime}$ when reflectance at visible and near-infrared wavelength bands is used to calculate $\alpha$. The influence of multi-scattering becomes larger when a value of crop LAI becomes larger, because multiscattering mainly depends on the LAI value. Therefore, the difference between fractions derived using reflectance at visible regions and reflectance from visible to near infrared regions indicates the influence of the LAI value, as follows:

$$
\begin{aligned}
L_{\text {dif }} & =\alpha_{v i s}-\alpha_{v i s+n i r} \\
& =\text { influence of multi scattering at near - infrared regions } \\
& \approx \text { influence of LAI }
\end{aligned}
$$

where $\alpha_{\mathrm{vis}}$ is the fraction of the target area to the unit ground area, and $\alpha_{\mathrm{vis}+n i r}$ is the fraction of the target area to the unit ground area including the influence of multi-scattering at nearinfrared wavelength bands.

To verify the availability of $L_{\text {dif }}$ under several LAI-coverage relationships, we set up two relationships (Fig. 18). This verification was performed using the radiative transfer model known as Forest Light Environmental Simulator (FliES), developed by Kobayashi and Iwabuchi [35]. FliES can simulate the reflectance at the top of the canopy under several conditions. LAI-coverage conditions were set up by changing the parameters such as plant density, leaf area density and plant size in FliES. The LAI used in this figure was measured by a field experiment conducted in the Kyoto University Experimental Field in 2008. Figure 19 is the time-series changes of conventional indices and the new index under two LAI-coverage conditions. The values of these indices range from 0 to 1 . This figure indicates that conventional indices are more sensitive to the change of coverage than is $L_{d i}$. Namely, the new index relates to only LAI under several planting forms. Fig. 20 shows the time-series changes of LAI and these indices. The values of each index in this figure were normalized using minimum and maximum values of each index. Table 9 shows root mean square errors of normalized vegetation indices for normalized LAI. This figure and table indicate that the normalized $L_{d i f}$ can directly depict the time-series pattern of the LAI. Hence, we believe our new index is more useful for estimating the LAI than conventional indices. Although $L_{d i f}$ is useful to estimate rice LAI, calculating the index value requires pure reflectance of the target object and maximum reflectance at each wavelength band. Generally, pure reflectance of rice may be measured during the heading period, because the coverage and LAI of rice are at maximum during this period. Maximum reflectance at visible wavelength bands may be measured before the transplanting period, and that at near-infrared regions may be measured during the heading period. Therefore, the setting of these reflectances for a target area should be discussed before 
applying this index in a future study. $L_{d i f}$ may be one of the most useful indices to estimate crop LAI when the way to set these reflectances is determined.

\begin{tabular}{ccccccccc}
\hline \multicolumn{10}{c}{ Normalized vegetation index } \\
\hline & N-NDVI 1 & N-NDVI 2 & N-EVI 1 & N-EVI 2 & N-SAVI 1 & N-SAVI 2 & N-Ldif 1 & N-Ldif 2 \\
\hline RMSE & 0.132 & 0.170 & 0.074 & 0.104 & 0.084 & 0.114 & 0.057 & 0.063 \\
\hline
\end{tabular}

Table 9. Root mean square errors of normalized vegetation index for normalized LAI

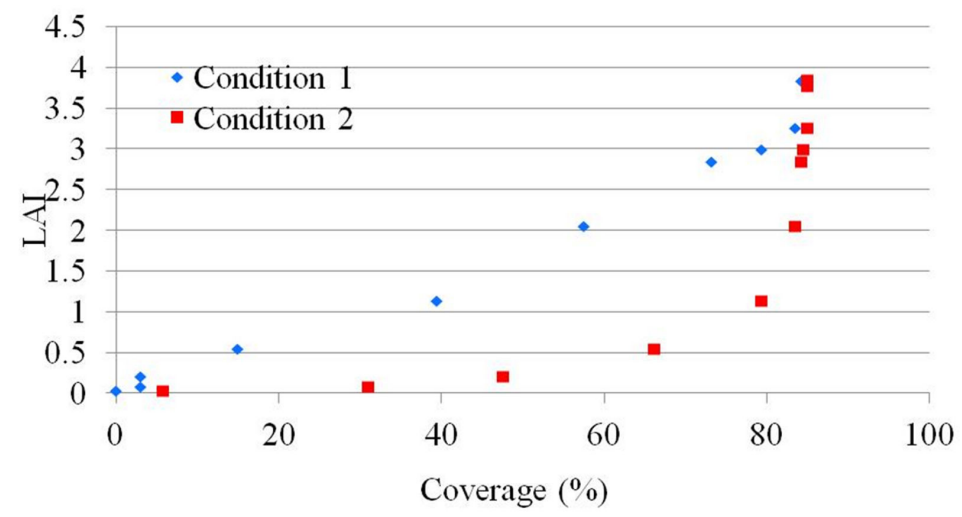

Figure 18. LAI-coverage relationships used to verify the availability of new index.
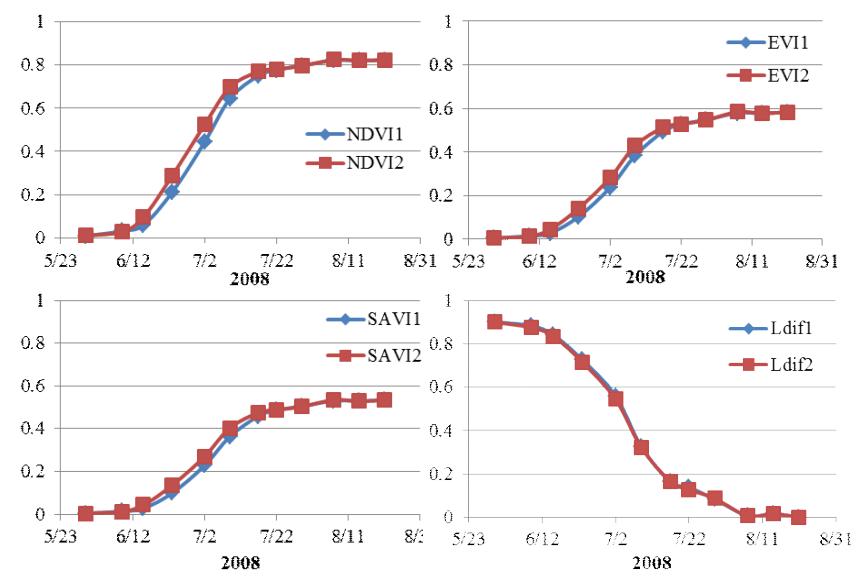

Figure 19. The time-series changes of vegetation indices under two LAl-coverage conditions. The suffixes of each index are corresponding to the suffixes of LAl-coverage conditions. 

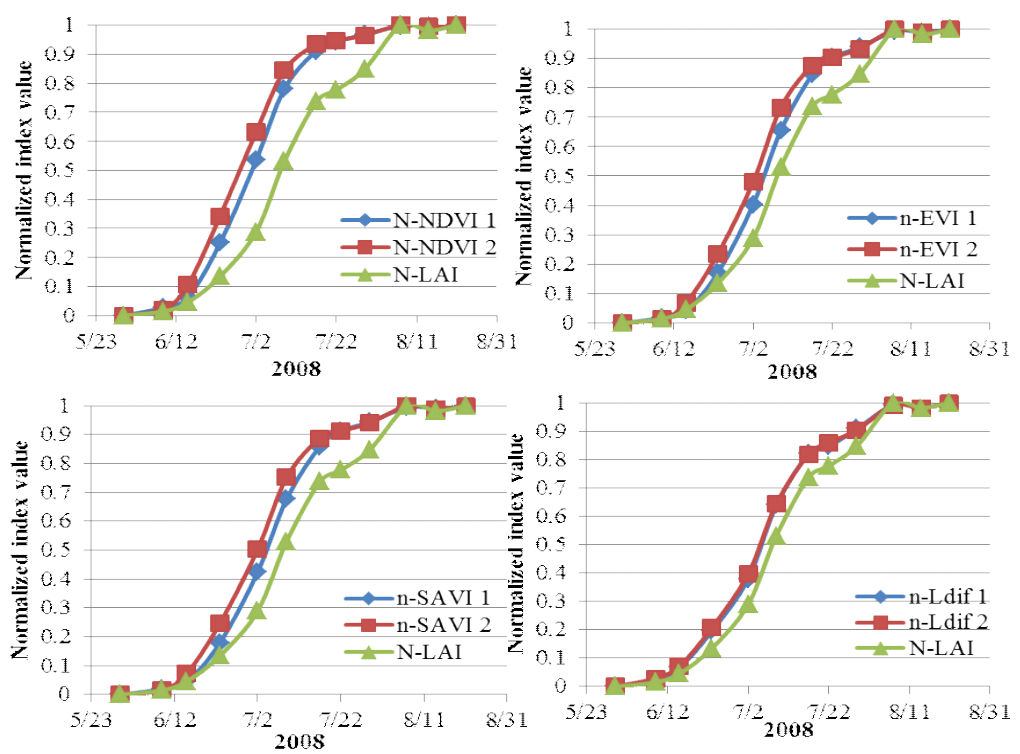

Figure 20. Time-series pattern of vegetation indices and LAI

\section{Impact of $2^{\text {nd }}$ generation biofuel development in Indonesia}

\subsection{1st generation and $2^{\text {nd }}$ generation biofuels}

To reduce the amount of imported fuel, lower the poverty ratio and reduce greenhouse gas (GHG) emissions, the Government of Indonesia is attempting to find alternative renewable energy, particularly in the form of biofuel. However, it is afraid that promotion of 1st generation biofuel produced primarily from food crops may cause deforestation or compete with food [36]. It is increasingly understood that 1st generation biofuels are limited in their ability to achieve targets for oil-product substitution. The cumulative impacts of these concerns have increased the interest in developing biofuels produced from non-food biomass, such as agricultural residues. These "2nd-generation biofuels" could avoid many of the concerns facing 1st generation biofuels. Some studies have estimated the potential of agricultural residuals, such as rice straw, for ethanol production [37,38]; however, little is known about the potential economic impact of producing 2 nd generation biofuels. The purpose of this part of our study was to estimate the potential production of rice straw for ethanol production and examine the possible economic impact of such production in Indonesia.

\subsection{The present situation of biofuel development and production in Indonesia}

The Government of Indonesia has released a new energy policy that aims at increasing energy self-sufficiency by publishing a road map for biofuel development as an alternative renewable 
energy based on the National Energy Policy (Presidential Decree No. 5/2006). This road map incorporates a plan to gradually increase the use of biofuels so that they accounts for $5 \%$ of the total energy supply by 2025. Table 10 shows details of the road map for increasing the use of biofuels. Among the biofuels proposed, biodiesel is made from palm oil and jatropha with the goal of having biodiesel account for $10 \%$ of total diesel consumption by $2005-2010,15 \%$ by 2011-2015 and $20 \%$ by 2016-2025. In the bioethanol sector, which uses sugar cane and cassava as feedstock, it is planned to increase the share of bioethanol of total gasoline consumption to $5 \%$ by 2005-2010,10\% by 2011-2015 and 15\% by 2016-2025. Based on these goals, it is estimated that 10.22 million kiloliters of biodiesel and 6.28 million kiloliters of bioethanol will be required per year by 2025 (Table 10). It is planned that cassava and sugar cane will be the major feedstock for bioethanol, while oil palm and jatropha will be the major feedstock for biodiesel. However, there is a wide gap between the potential consumption and actual consumption (Fig.21). Indonesia's fuel ethanol production has remained at the zero level since 2010 due to disagreement in market price index formulation between MEMR (The Indonesian Ministry of Energy and Mineral Resources) and ethanol producers [39]. Moreover, it is not easy to increase the production of feedstock of bioethanol without forest degradation. Moon and Shirakawa [36] point out that in the case of $1^{\text {st }}$ generation biofuel, deforestation is inevitable to achieve Indonesia's biofuel provision target, and there will be a negative effect of increasing the net $\mathrm{CO} 2$ emission due to massive expansion of land use for biofuel cultivation. On the other hand, there is great potential for ethanol productionfromagriculturalresiduesinIndonesia[37]. Therefore, itisimportanttodevelopthenecessary technology to produce bioethanol from agricultural residues, especially from rice straw.

\begin{tabular}{|c|c|c|c|c|}
\hline & & $2005-2010$ & 2011-2015 & 2016-2025 \\
\hline \multirow{2}{*}{$\begin{array}{c}\text { Biodiesel } \\
\text { (Palm oil, Jatropha) }\end{array}$} & Plan & $\begin{array}{c}10 \% \text { of Biodiesel of total } \\
\text { Diesel consumption }\end{array}$ & $\begin{array}{c}15 \% \text { of Biodiesel of total } \\
\text { Diesel consumption }\end{array}$ & $\begin{array}{c}20 \% \text { of Biodiesel of total } \\
\text { Diesel consumption }\end{array}$ \\
\hline & Amount & 2.41 million $\mathrm{kl}$ & 4.52 million $\mathrm{kl}$ & 10.22 million kl \\
\hline \multirow{2}{*}{$\begin{array}{c}\text { Bioethanol } \\
\text { (Sugar cane, Cassava) }\end{array}$} & Plan & $\begin{array}{l}5 \% \text { of Bioethanol of total } \\
\text { Gasoline consumption }\end{array}$ & $\begin{array}{c}10 \% \text { of Bioethanol of total } \\
\text { Gasoline consumption }\end{array}$ & $\begin{array}{c}15 \% \text { of Bioethanol of total } \\
\text { Gasoline consumption }\end{array}$ \\
\hline & Amount & 1.48 million kl & 2.78 million kl & 6.28 million $\mathrm{kl}$ \\
\hline \multirow{2}{*}{ Biooil } & Plan & Using Bio Kerosene & Using Bio Kerosene & Using Bio Kerosene \\
\hline & Amount & 1.00 million $\mathrm{kl}$ & 1.80 million $\mathrm{kl}$ & 4.07 million $\mathrm{kl}$ \\
\hline \multirow{2}{*}{$\begin{array}{c}\text { Pure } \\
\text { plantation oil }\end{array}$} & Plan & Using PPO & Using PPO & Using PPO \\
\hline & Amount & 0.40 million $\mathrm{kl}$ & 0.74 million $\mathrm{kl}$ & 1.69 million kl \\
\hline \multirow[t]{2}{*}{ Total Biofuel } & Plan & $\begin{array}{l}2 \% \text { of Biofuel of total } \\
\text { Energy consumption }\end{array}$ & $\begin{array}{l}3 \% \text { of Biofuel of total } \\
\text { Energy consumption }\end{array}$ & $\begin{array}{l}5 \% \text { of Biofuel of total } \\
\text { Energy consumption }\end{array}$ \\
\hline & Amount & 5.29 million kl & 9.84 million kl & 22.26 million $\mathrm{kl}$ \\
\hline $\begin{array}{l}\text { * Source: National Plan } \\
\text { * PPO: Pure Plantation } \\
\text { * kl: Kiloliter }\end{array}$ & on Biofue & $\begin{array}{l}\text { " 'Development of Alternati } \\
\text { ved from jatropha) }\end{array}$ & ve Energy in Indonesia". & \\
\hline
\end{tabular}

Table 10. Roadmap for increasing use of biofuel in Indonesia 

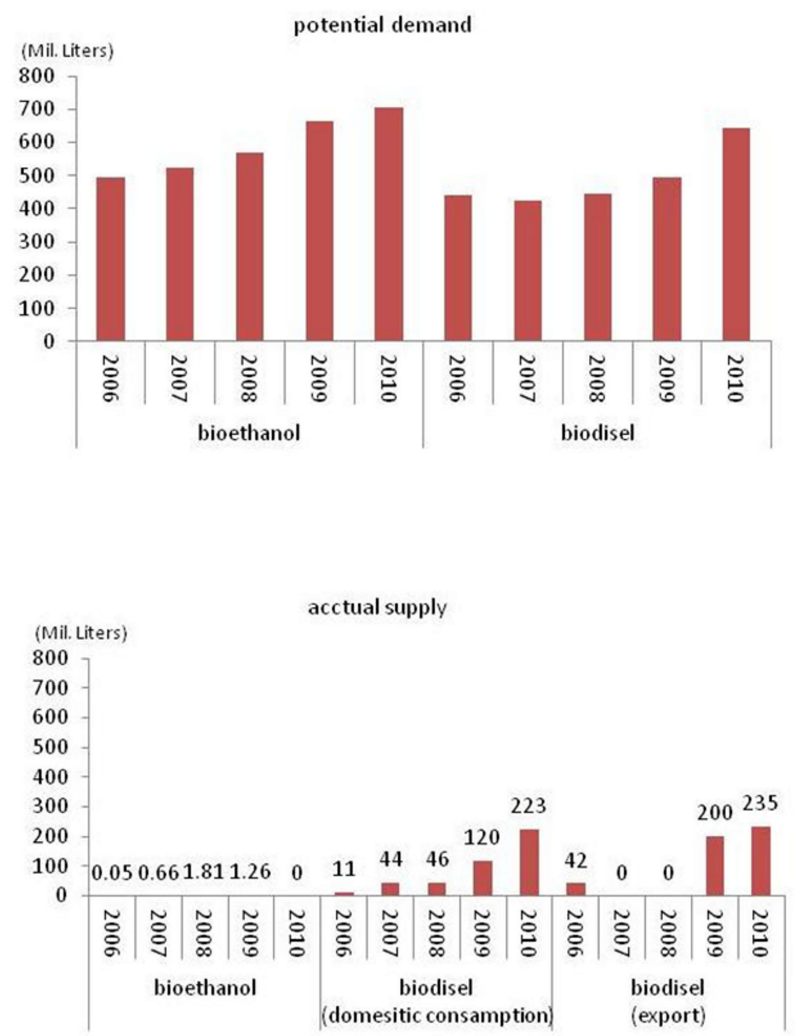

Note: potential consumption is equal to bending rate multiplied by gasoline / diesel oil consumption. Source: [39]

Figure 21. Indonesia biofuel use in transportation sector.

\section{Proposal of a poverty alleviation policy for farmers as an example of an environmentally advanced basin model in Asia with a focus on water, food and energy}

In this section, we propose a scenario for alleviating farmers' poverty that activates unused resources in the Cihea irrigation area. As unused resources, water resource development and rice straw are assumed.

1. Water resource development

Figure 22 shows precipitation, river discharge and intake water for irrigation. Each value is the monthly average for 9 years (2001 to 2009). As mentioned above, the Cisokan River does not have any large water storage in the upstream area, and water intake depends on the natural 
river discharge. This results in a big seasonal fluctuation of available water from the river, and the water supply is not sufficient for irrigation in the dry season.

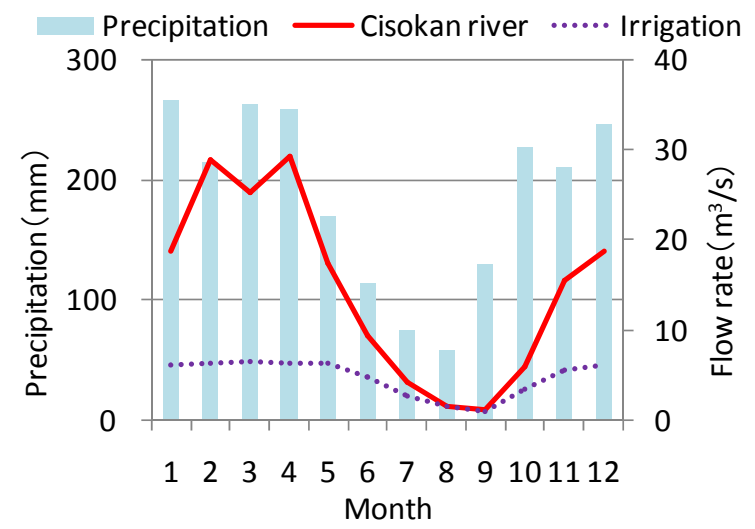

Figure 22. Precipitation, river discharge, and water intake for irrigation (monthly average data from 2001 to 2009 ).

The daily water demand was calculated as the sum of evapotranspiration ( $5 \mathrm{~mm} /$ day) and infiltration (10 mm/day), and the irrigation water surplus/shortage was estimated by comparing the daily water demand with the intake water and effective rainfall. After estimating the amount of irrigation water, we determined that the water shortage in the dry season and surplus in the rainy season would be $7.1 \mathrm{~mm} /$ day and $25.4 \mathrm{~mm} /$ day, respectively, and if onethird of the water surplus in rainy season could be stored, enough water would be supplied for rice production in the dry season over the entire irrigation area. Furthermore, since the solar radiation in the dry season is more than that in the rainy season, the yield in the dry season is expected to be more than that in the rainy season.

2. Economic Impact of Biofuel Development from Rice Straw

In the Citarum River Basin, most rice straw is burned, with a small part of it used for feeding. This unused resource can be utilized as a material for bioethanol. If rice straw left over after harvest is used, it would have a positive economic impact on farmers, both because of selling it and in the form of payment for collection.

We conducted field survey in this area in Jul. 2010 and Mar. 2011. As a result, the average rice grain yield in the rainy season was $5.8 \mathrm{t} /$ ha (fresh weight). The rice straw produced can thus be calculated as follows:

$5.8 \mathrm{t} / \mathrm{ha} \times 2 / 3 \times 1.55 .8 \mathrm{t} / \mathrm{ha}$ 
where it is assumed that the dry weight is $2 / 3$ of the fresh weight and the rice straw weight is 1.5 times the dry weight.

As a model case, we estimated the economic impact that can be expected by activating unused resources for a typical household, that is, $\mathrm{NF}=4$ (parents and two children), HA $=0.26$ ha and without side jobs. In this case, the values associated with rice production are estimated as follows:

$\mathrm{P}=2.0 \mathrm{t} / \mathrm{yr}, \mathrm{S}=1.6 \mathrm{t} / \mathrm{yr}$ and $\mathrm{INC}=4.7 \times 10^{6} \mathrm{Rp} / \mathrm{yr}$

As mentioned above, in the Citarum River Basin, water resource development would enable three annual planting times, and thus the value of INC would increase to $8.0 \times 10^{6} \mathrm{Rp} / \mathrm{yr}$.

When rice straw is used as a material of bioethanol, the income from selling and collecting the rice straw can be expected. The economic impact of selling rice straw is estimated using the price of $100 \mathrm{Rp} / \mathrm{kg}$, while it is considered to be 0 to $200 \mathrm{Rp} / \mathrm{kg}$ for feeding in Indonesia. The annual income from selling rice straw is thus estimated as follows:

$0.26 \mathrm{ha} \times 5.8 \times 10^{5} \mathrm{Rp} / \mathrm{ha} \times 2$ harvest times $/ \mathrm{yr}=3.0 \times 10^{5} \mathrm{Rp} / \mathrm{yr}$

This value is equal to $6.3 \%$ of INC. To collect rice straw after harvest, the amount of work is assumed to be 3 day/ha by one person (Saga et al. 2008), and payment for collection is assumed to be the same as for harvest, $4.0 \times 10^{4} \mathrm{Rp} /$ day. The income of farmers from collection is estimated as follows:

0.26 ha $\times 2$ harvest times $\times 3$ days $/$ ha $\times\left(4.0 \times 10^{4} \mathrm{Rp} /\right.$ day $)=6.2 \times 10^{4} \mathrm{Rp} / \mathrm{yr}$

These estimates are summarized in Table 2. Planting three times per year by the development of water resource and making bioethanol from rice straw would enable farmers to increase their income by $3.7 \times 10^{6} \mathrm{Rp} / \mathrm{yr}$, up to a 1.8 -fold increase.

\section{Conclusions}

In this study, we carried out the following:

1. Outline the current status of agricultural life in the Citarum River Basin in Indonesia.

2. Quantify the uneven distribution of water resources and change in nitrogen load at the basin level, and assess the varietal diversity against the drought risk.

3. Assess the paddy rice yields with remotely sensed data.

4. Propose a simulation model combined with remote sensing to evaluate geographical distributions of rice growth and yield.

5. Outline a strategy for the sustainable use of biomass energy at the regional and basin levels.

Utilizing the preceding five items, we proposed an environmentally advanced basin model in the Cihea irrigation area. In particular, we proposed a poverty alleviation policy for farmers 
as an example of an environmentally advanced basin model in Asia with a focus on water, food and energy.

Rice is the most important crop in Indonesia, and large quantities of rice residues in the form of straw are available. Our findings show that the production of biofuel will contribute to poverty alleviation. However, rice straw is also used for organic fertilizer. It is necessary to determine what percentage of rice straw could be used for bioethanol from the viewpoint of a sustainable rice yield. The cost of ethanol production from rice straw is still higher than the cost of gasoline; however, the production of bioethanol from agricultural residuals could create jobs and contribute positively to the energy security issue. We need to consider the cost-benefit of biofuel production not only on the plant level but also on the social level.

Our study results confirm the necessity of taking measures to improve the present paddy rice production system. It is estimated that the three-times production per year made possible by the development of the water resource and making bioethanol from rice straw would enable farmers to increase their income up to 1.8 -fold.

Regarding future plans, it is necessary to form a cooperative relationship among local government, researchers and agricultural stakeholders and examine more concretely the possibility of conducting the suggested measures in real society to alleviate the poverty of farmers.

\section{Acknowledgements}

This research was supported by environment research \& technology development fund (E-1104: Development and Practice of Advanced Basin Model in Asia : Toward Adaptation of Climate Changes (FY2011-FY2013), Ministry of the Environment, Japan). We would like to express our gratitude for its financial aid.

\section{Author details}

Kazuo Oki ${ }^{1}$, Keigo Noda ${ }^{1}$, Koshi Yoshida ${ }^{2}$, Issaku Azechi ${ }^{2}$, Masayasu Maki ${ }^{3}$, Koki Homma ${ }^{3}$, Chiharu Hongo ${ }^{4}$ and Hiroaki Shirakawa ${ }^{5}$

1 The University of Tokyo, Japan

2 Ibaraki University, Japan

3 Kyoto University, Japan

4 Chiba University, Japan

5 Nagoya University, Japan 


\section{References}

[1] BPSDA(Balai Pengelolaan Sumber Daya Air)((2006). Status Report Balai PSDA WSCitarum (in Indonesian)

[2] Loebis, J, \& Syamman, P. (1993). Reservoir operation conflict in Citarum river basin management, IAHS Pub. , 213, 455-459.

[3] ADB(Asian Development Bank) ((2004). Technical assistance to the republic of Indonesia for preparing the integrated Citarum water resources management projectADB report TAR: INO 37049, Directorate General for Water Resources, Ministry of Public Works, Jakarta.

[4] Basyar, P. A, \& Harto, B. (2006). Spatial modeling of sediment transport over the upper Citarum catchment, PROC. ITB Eng. Science, 38(1), 11-27.

[5] Pirard, R, \& Bille, R. (2010). Payments for Environmental Services (PES): a reality check (stories from Indonesi), Analyses IDDRI.(3)

[6] BBWSC(Balai Besar Wilayah Sungai Citarum) (2011): Profil BBWSC (in Indonesian).

[7] Beven, K. J, \& Kirkby, M. J. (1979). A physically based, variable contributing area model of hydrology., Hydrological science bulletin. 24(1), 43-69.

[8] Ao, T, Ishihira, H, \& Takeuchi, K. (1999). Study of Distributed Runoff Simulation Model Based On Block Type Topmodel and Muskingum-Cunge Method, Annu. J. of Hydr. Eng., , 43, 7-12.

[9] NawarathnaNMNS B., Ao, T. Q., K azama, S., Sawamoto, M. and Takeuchi, K. ((2001). Influence of Human Activity on the BTOPMC Model Runoff Simulations in Large-scale Watersheds., XXIX IAHR congress proceedings, theme a, , 93-99.

[10] Fares, Y. R. (2003). Water resources management in tropical river catchments.,journal of Environmental Hydrology. no. Papers 14, , 11, 1-11.

[11] FAO : Livestock density (GEONETWORK)(2005). http://www.fao.org/AG/againfo/ resources/en/glw/ GLW_dens.html.

[12] Kunimatsu, T, \& Muraoka, K. (1989). Model Analysis of River Pollution (in Japanese), Gihoudo Press(Tokyo).

[13] Bouvet, A. Le Toan, T. and Lam-Dao, N. ((2009). Monitoring of the rice cropping system in the Mekong delta using ENVISAT/ASAR dual polarization data. IEEE Trans. Geoscience and Remote Sensing, 47, , 517-526.

[14] Pan, X. Z, Uchida, S, Liang, Y, Hirano, A, \& Sun, B. (2010). Discriminating different landuse types by using multitemporal NDXI in a rice planting area. International Journal of Remote Sensing, , 31, 585-596. 
[15] Niel, T. G. V, \& Mcvicar, T. R. (2003). A Simple method to improve field-level rice identification: toward operational monitoring with satellite remote sensing. Australian Journal of Experimental Agriculture, , 43, 379-387.

[16] Ahlrichs, J. S, \& Bauer, M. E. (1983). Relation of agronomic and multispectral reflectance characteristics of spring wheat canopies. Agronomy Journal, , 75, 987-993.

[17] Patel, N. K, Singh, T. P, Sahai, B, \& Patel, M. S. (1985). Spectral response of rice crop and its relation to yield and yield attributes. International Journal of Remote Sensing, , 6, 657-664.

[18] Barnett, T. L, \& Thompson, D. R. (1982). The use of large-area spectral data in wheat yield estimation. Remote Sensing of Environment, , 12, 509-518.

[19] Nuarsa, I. W, Nishio, F, \& Hongo, C. (2011). Relationship between Rice Spectral and Rice Yield Using Modis Data, Journal of Agriculture Science, Canada, , 3(2)

[20] Nuarsa, I. W, Nishio, F, \& Hongo, C. (2012). Rice Yield Estimation Using Landsat ETM+ Data and Field Observation, Journal of Agriculture Science, Canada, , 4(3)

[21] Nuarsa, I. W, Nishio, F, \& Hongo, C. (2011). Spectral characteristic comparison of rice plants under healthy and water deficient conditions using Landsat RTM+ data, Journal of the Japan Society of Photogrammetry and Remote Sensing, , 50(2)

[22] Homma, K, Maki, M, \& Hirooka, Y. (2012). Toward to develop a simulation model to evaluate geographical distributions of rice growth and yield. Jpn J. Crop Sci. 81 (Extra (1)

[23] Horie, T. (1987). A model for evaluating climatic productivity and water balance of irrigated rice and its application to Southeast Asia. South Asia Studies , 25, 62-74.

[24] Homma, K, \& Horie, T. (2009). The present situation and the future improvement of fertilizer applications by farmers in rainfed rice culture in Northeast Thailand. In: L.R. Elsworth, W.O. Paley (Eds.) Fertilizers: Properties, Applications and Effects. Nova Science Publishers, N.Y. , 147-180.

[25] Horie, T, Nakagawa, H, Centeno, H. G. S, \& Kropff, M. (1995). The rice crop simulation model SIMRIW and its testing. In Modelling the Impact of Climate Change on Rice in Asia (Matthews, R. B. et al. eds.), CAB International, Oxon, UK. , 51-66.

[26] Tanaka, K, Kiura, T, Sugimura, M, Ninomiya, S, \& Mizoguchi, M. (2011). Tool for predicting the possibility of rice cultivation using SIMRIW. Agric. Inform. Res. , 20, $1-12$.

[27] Nakagawa, H, \& Horie, T. (1995). Modeling and prediction of developmental process in rice. II. A model for simulating panicle development based on daily photoperiod and temperature. Jpn. J. Crop Sci. , 64, 33-42. 
[28] Nakagawa, H, \& Horie, T. (1997). Phenology determination in rice. In: Breeding Strategies for rainfed lowland rice in drought-prone environments (Fukai, S. et al. eds.). Australian Centre for International Agricultural Research, Canberra. , 81-88.

[29] Rouse, J. W, Haas, R. H, Schell, J. A, Deering, D. W, \& Harlan, J. C. (1974). Monitoring the vernal advancement and retrogradation of natural vegetation. NASA/GSFC Final Report, , 1-137.

[30] Baret, F, \& Guyot, G. (1991). Potentials and limits of vegetation indices for LAI and APAR assessment. Remote Sensing of Environment , 35, 161-173.

[31] Liu, H. Q, \& Huete, A. R. (1995). A feedback based modification of the NDV I to minimize canopy background and atmospheric noise. IEEE Transactions on Geoscience and Remote Sensing , 33, 457-465.

[32] Huete, A. R, \& Justice, C. (1999). MODIS vegetation index (MOD13) algorithm theoretical basis document. NASA EOS MODIS Doc., Version 3.0.

[33] Huete, A. R. vegetation index (SAVI). Remote Sensing of Environment, 25, 295-309.

[34] Oki, K, \& Oguma, H. (2002). Estimation of the canopy coverage in specific forest using remotely sensed data- Estimation of Alder trees in the Kushiro Mire-. Journal of the Remote Sensing Society of Japan , 22, 510-516.

[35] Kobayashi, H, \& Iwabuchi, H. D atmosphere and 3-D canopy radiative transfer model for canopy reflectance, light environment, and photosynthesis simulation in a heterogeneous landscape. Remote Sensing of Environment, 112, 173-185.

[36] Moon, D, \& Shirakawa, H. (2012). Increase in biofuel use and corresponding changes in land use in Indonesia, Journal of Environmental Information Science, , 40(5), 69-78.

[37] Yano, S. (2010). Study on Bioethanol Production From Agricultural Residuals in Asia, http://repository.dl.itc.u-tokyo.ac.jp/dspace/bitstream/2261/37429/1/39_077098.pdf

[38] Diep, N. Q, Fujimoto, S, Minowa, T, Sakanishi, K, \& Nakagoshi, N. (2012). Estimaion of the potential of rice straw for ethanol production and the optimum facility size for different regions in Vietnam, Applied Energy, , 93, 205-211.

[39] USDA foreign Agricultural ServiceIndonesia Biofuel Annual ((2011). http:// gain.fas.usda.gov/Recent\%20GAIN\%20Publications/Biofuels\%20Annual_Jakarta_Indonesia_8-19-2011.pdf 